\title{
TUTAMEIA: A LINGUAGEM E A ESTRUTURA DA OBRA EM SINTONIA COM A (I)LÓGICA DA VIDA
}

\author{
Ana Maria Rocha Soares* \\ Márcio Roberto Soares Dias ${ }^{* *}$
}

RESUMO: O presente artigo traz em seu bojo o papel inusitado que Guimarães Rosa confere aos prefácios quando da construção e estruturação da obra Tutameia. Discute-se como a(s) temática(s) e estruturação da referida obra já se revelam pela organicidade dos prefácios: os motivos já se delineiam em quatro narrativas que funcionam, a um só tempo, como prefácios e como histórias que complementam o repertório dos quarenta contos que compõem a obra. Vislumbra-se, desse modo, como tais prefácios conseguem amalgamar reflexões, pistas de leitura e escrita, metalinguagem, histórias e estórias, conservando, simultaneamente, a integridade (dos prefácios e demais narrativas) e a garantida dos elementos constitutivos do todo de obra que é Tutameia. Jogo performativo esse com que o prosador nos dá uma amostra de obra que não só questiona o próprio fazer literário, como também reflete e nos apresenta amostra(s) de vida, que - assim como a obra - apresenta seus inesgotáveis motivos que merecem (e devem) ser lidos.

PALAVRAS-CHAVE: Guimarães Rosa; Estrutura; Prefácios; Procedimento metalinguístico; Tutameia.

\section{Os prefácios na lógica estrutural de Tutameia}

Em Tutameia, de Guimarães Rosa, a estrutura e a linguagem são operadas numa perspectiva inusitada; a lógica de organização da referida obra se revela tanto como projeção de um mundo rural - sertanejo -, assim também como uma lógica que projeta o fazer literário: a projeção de uma nova forma de conceber e efetivar a prática de escrita; uma nova

\footnotetext{
* Mestre em Letras: Cultura, Educação e Linguagens pela Universidade Estadual do Sudoeste da Bahia (Uesb).

** Doutor em Letras pela Universidade Federal da Bahia (Ufba). Professor titular da Uesb.
} 
postura - de escrita e leitura - que se revela, por conseguinte, num experimentalismo de estruturação e de construção literária.

$\mathrm{E}$, nesse intento, os desdobramentos do autor mineiro se perfazem na própria estrutura da obra. Tutameia reflete - e revela - um projeto de escrita que se mostra de uma maneira um tanto inusitada: de uma unidade que se perfaz pela diversidade; do mesmo modo com que, partindo dessa diversidade - das quarenta estórias, além dos quatro prefácios -, ela se configura em unidade (a obra como um todo). As Terceiras estórias (ou Tutameia) se revelam aí como configuração de obra que se quer reconhecida em novas formas de expressão e de realização literária.

A estrutura de Tutameia se configura numa lógica peculiar de obra que pode ser assim caracterizada: são quarenta narrativas subdivididas por quatro unidades que garantem a conexão e a concatenação entre os elementos dentro de uma unidade de obra; são quarenta estórias cujos espaços e alguns personagens se repetem, se entrelaçam, se complementam, se identificam e também se incompatibilizam. A compreensão do todo - obra remete, assim, à compreensão das unidades - todo - dos contos e prefácios. Uma relação paradoxal que se organiza pela independência quanto pela dependência mútua entre as partes e o todo.

Pode-se, assim, dizer que os prefácios funcionam não somente como elementos de conexão entre as estórias, ou mesmo um direcionamento para as questões e abordagens mais significativas da obra, mas também se inscrevem em Tutameia como ponto específico de reflexão e de sugestão para uma prática de escrita e de leitura diferenciada daquilo que se caracteriza como prática literária corrente. É, pois, pelos prefácios que as "veredas" da literatura (e da língua) buscam acompanhar os itinerários e ritmo da vida.

Importante destacar o caráter inovador das Terceiras estórias até mesmo na estrutura e disposição desses prefácios: a começar por um número nada usual - quatro, em vez de um (o convencional) -; além disso, sua função na obra ultrapassa, e muito, o mero papel de norteador ou facilitador de leitura. Seu papel, além desse, se revela tanto como instrumento "teorizante" ou metalinguístico, quanto como recurso estilístico e, como tal, objeto 
estético digno de apreciação e de crítica. Afinal, eles, além de prefácios, caracterizam-se também como estórias.

Nesse sentido, os prefácios assumem papel decisivo na estruturação e efetivação da respectiva obra e, portanto, na "consubstanciação" da(s) consequente(s) leitura(s), já que eles funcionam como estórias-núcleo que, intercaladas a essa inerente disposição de Tutameia, funcionam como termos integrantes que "enredam" e dão uma prévia noção (ou menção) dos motivos, bem como dos recursos linguísticos responsáveis pela re/estruturação e efetivação de novas formas de escrita.

Pode-se dizer que eles figuram como "ponto paragem" de revigoramento para as leituras subsequentes, bem como para reflexão atinente à língua e à própria construção (de obra) que se engendra no percurso, ou nas veredas, da leitura de Tutameia. Os prefácios conseguem, assim, amalgamar reflexões, pistas de leitura e escrita, metalinguagem, histórias e estórias, conservando, simultaneamente, sua integridade enquanto elemento constitutivo de um todo (da obra), assim como de um todo enquanto texto independente (conto). Assim, eles ordenam e coordenam; dirigem e se submetem ao todo. Sobressaem-se como protagonistas - texto todo - do mesmo modo com que se revelam como coadjuvantes, integrantes do todo das Terceiras estórias.

Acresce-se a isso o espaço - ou cenários - das narrativas: as quarenta estórias quase sempre são ambientadas em meio a uma estrada, a um percurso ou margem de rio, a uma mata ou serra em que perfilam personagens cujo destino é incerto, porém promissor; caminhos em que homens e mulheres vivem na expectativa de um porvir - talvez - venturoso...

A sutileza e simplicidade das histórias de vida; o dinamismo, bem como a morosidade da vida rústica do interior mineiro são "captados" pela sensibilidade e olhos do nosso escritor e, em seguida, mediatizados pelo "senso de projeção" disponibilizado na escrita. O próprio Rosa já afirmara em entrevista anteriormente citada: "Renovar a língua para renovar o mundo" (LORENZ, 1995). 
O próprio título da obra já pressupõe uma (re)atualização da língua. Palavra que, conforme os estudos filológicos de João Ribeiro (apud CAMPOS, 2011, p. 52), é formada pela aglutinação da expressão "tuta-e-meia" - que significa "ninharia” -, o termo "Tutameia" resulta dessa junção inusitada que revela, e faz vir à tona, vocábulos que, até o momento, se encontravam em desuso.

Daí destacar o trabalho do autor quando ao enveredar por uma via de mão dupla: ao mesmo tempo em que ele consegue "regionalizar" valores universais, consegue, inversamente, fazer do circunstancial ou específico algo de caráter, ou preocupação, existencial e, portanto, universal. Ele, ao mesmo tempo em que "desterritorializa" - quando eleva situações ou fatos locais a uma dimensão mais abrangente -, do mesmo modo "terriotarializa" - quando compatibiliza vivências, experiências, anseios e angústias de homens cuja realidade se concebe - ou aparenta - um tanto distante ou antagônica em relação a um mundo maior. Eis, segundo a maior parte da crítica, um dos maiores empreendimentos do prosador (ou poeta): conseguir inovar um regionalismo ${ }^{1}$ que, aos olhos da maioria dos seus contemporâneos, já se encontrava um tanto quanto saturado.

As dúvidas, preocupações, desejos e angústias de um homem de dada região - sertanejo, rural, jagunço, vaqueiro - conseguem ser as mesmas que afligem o homem oriundo de um espaço cultural e geográfico díspar. Desse modo, quando ao universalizar valores de uma região específica, ou quando ao regionalizar aspectos universais, ele o faz de modo a preservar e considerar as singularidades e diferenças culturais próprias de qualquer homem, ou de qualquer lugar específico. E isso ele o faz muito bem por ser, conforme Fantini (2003), um autor que transita entre duas realidades distintas. Segundo a estudiosa, aquilo que se tem como limites politicamente demarcados (geográficos, socioculturais) acabam desaparecendo na obra do escritor mineiro.

\footnotetext{
${ }^{1} \mathrm{O}$ termo, aqui usado, faz alusão à perspectiva costumeiramente adotada pela história da literatura desde o século XIX, mas hoje superada, que é a postura que toma a brasilidade como critério definidor de uma suposta autonomia no campo artístico e cultural e, portanto, como elemento representativo de diferenciação da cultura brasileira em relação à cultura estrangeira (sobretudo a europeia).
} 
Ademais, a região - sertão mineiro, que é foco de sua obra - é, conforme relatos de familiares e amigos e também em entrevistas do próprio autor -, espaço bem familiar para o ficcionista. Rosa conheceu de perto a cultura, os valores e as idiossincrasias desse povo: primeiramente, por ser também oriundo dessa região e por ter passado boa parte de sua vida nesse espaço; segundo, pelas viagens empreendidas em visita a locais específicos que estariam retratados em sua obra.

O próprio Rosa afirmara em entrevista concedida ao jornalista português Arnaldo Saraiva:

Quando escrevo, não penso na literatura: penso em capturar coisas vivas. Foi a necessidade de capturar coisas vivas, junta à minha repulsa física pelo lugar-comum (e o lugar-comum nunca se confunde com a simplicidade), que me levou à outra necessidade íntima de enriquecer e embelezar a língua, tornando-a mais plástica, mais flexível, mais viva. (REVISTA BULA, 24 de nov. de 1966. Publicada no livro Conversas com Escritores Brasileiros)

A habilidade que o prosador/poeta tem de absorver as mudanças e premências sociais e culturais é a mesma com que ele atua quando para restituir ou resgatar aquelas manifestações solapadas pela ação - ou efeito - da modernização. Eis aí o seu papel de mediador.

Cumpre destacar que o diferencial dos prefácios caracteriza-se pelo seu duplo (ou melhor, triplo) papel: são narrativas ao mesmo tempo em que são reflexões e "teoria"; são estórias contadas com uma presteza de encantamento na mesma medida em que se prestam à reflexão atinente ao papel que a linguagem pode assumir diante das histórias (que se querem estórias) da vida; são, ademais, digressões que impelem o leitor a refletir o papel da língua e do ato criador imanente tanto ao momento de escrita quanto ao de leitura (e, por conseguinte, efetivação) da obra.

Segundo Simões (1988), os prefácios figuram como guias ou pistas de leitura da obra, o que a estudiosa chama de "parâmetros disfarçados". Pode-se dizer, assim, que eles "desorganizam" na mesma medida em que organizam uma estrutura de obra; rompem com uma típica linearidade na mesma proporção em que direcionam para uma linearidade de 
leitura e escrita. A perspectiva dos prefácios é, sobretudo, aquela que desconstrói o convencional, mas que, por outro lado, viabiliza novas possibilidades de produção e de leitura da obra literária.

\section{"Aletria e hermenêutica": de que a vida pode ser lida pelo anedótico}

Publicado em 1954, no periódico Letras e Artes, sob o título de "Risada e meia", o prefácio "Aletria e hermenêutica" é o que abre as 44 narrativas que compõem Tutameia. Através dele, Rosa confere à anedota o papel de sensibilização e de suporte para uma nova "realidade”, para “dimensões mágicas”, ou - mais precisamente - para reflexões mais profundas acerca da vida. Com ele, o prosador aponta a possibilidade de a vida (a história) ser revelada pela linguagem figurada, sobretudo pelo anedótico.

Desse modo, o que seria delegado às aporias metafísicas pode muito bem ser compensado pelo caminho de uma descoberta que se faz pelo óbvio e simples da vida. Afinal, o complexo e sério pode ser amenizado, se não revelado, quando conduzido ao prosaico porém encantatório - e "sublime" da vida. Porquanto o prosaico e simples (porém profundo) do mundo pode e deve ser traduzido pelo tão prosaico e simples quanto prazeroso de uma anedota. Eis a forma encontrada:

Por onde, pelo comum, poder-se corrigir o ridículo ou o grotesco, até levá-los ao sublime; seja daí que seu entre-limite é tão tênue. E não será esse um caminho por onde o perfeitíssimo se alcança? Sempre que algo de importante e grande se faz, houve um silogismo inconcluso, ou, digamos, um pulo do cômico ao excelso. (ROSA. 2009, p. 39)

Desse modo, com "Aletria e hermenêutica", Rosa ilustra, mediante pequenas blagues, como a anedota consegue fazer refletir o sério da vida, assim como leva a aprender, a partir do prosaico, as coisas do mundo assim como da obra literária. Rosa apresenta a proposta do "não senso", de um espaço para o que está além da "vida real"; a perspectiva de que "A vida também é para ser lida" (ROSA, 2009, p. 31). na perspectiva figurada, anedótica. 
De fundo filosófico e teórico, o prefácio aponta caminhos para novas "veredas" de escritura (e leitura) literária, bem como de um novo trilhar pela linguagem. Nesse sentido, o prefácio corrobora um Rosa consciente das inúmeras possibilidades de que uma língua é suscetível e, por conseguinte, atesta a flexibilidade com que o ficcionista trata as variedades linguísticas que se distanciam daquela consagrada por um grupo de prestígio. Sobre o referido prefácio, Nunes (1969) pondera:

Parece-nos, então, que o primeiro prefácio estabelece a perspectiva dentro da qual as estórias podem ser colocadas. Ele fixa a hermenêutica, não de cada conto particular, mas de todos em conjunto a hermenêutica da estória que há nas estórias. (p. 206)

Tem-se aí a proposta de o circunstancial e o episódico serem regrados pelo humor. Portanto, "desautomatizando" o percurso convencional da história (ou melhor, estória) contada, o autor disponibiliza um espaço (em brincadeira) de um "desvio" momentâneo do aparente grotesco para uma "tomada de consciência" atinente às inquietações e expectativas do homem comum e do homem (escritor). Daí concordar que, se com Tutameia "O livro pode valer pelo muito que nele não deveu caber" (ROSA, 2009, p. 40), a "anedota" deve valer pelo muito que deveu caber do muito que se subtraiu do livro.

Em se tratando do título do prefácio, faz-se necessário conhecer a significação dos vocábulos que o compõem. Conforme dicionário Aurélio (FERREIRA, 1999), “aletria”, cuja origem é do árabe al-itraya(t), 'fio' pode assumir as seguintes significações: (1) Massa de farinha de trigo em fios delgados, usada em sopas ou preparada com ovos, leite e açúcar, e que tem como variante letria: cabelo de anjo, fidelinho; (2) na Zoologia, significa manjuba. Desse modo, considerando o aludido vocábulo associado ao outro - "hermenêutica" -, cujo significado remete a uma "interpretação", talvez seja lícito adotar, nesta pesquisa, a definição (1) de "aletria" de modo a considerar, ademais, possibilidade(s) de sentido figurado das palavras que nossa língua nos permite.

Ademais, sobre o uso do termo "aletria", podemos fazer mais uma inferência. Há a possibilidade de Rosa tê-la usado numa associação ao termo "aletheia" cuja origem remonta à Grécia antiga: segundo a mitologia, "Aletheia" é o nome da deusa da verdade e, como tal, 
seu significado remete à busca de compreensão da realidade, ou seja, a busca da verdade das coisas. "Aletheia” implica, pois, uma espécie de epifania, uma revelação (ou o "desencobrimento") de algo encoberto; “desencavar" uma suposta verdade, processo esse que se faz possível mediante uma "hermenêutica".

Quanto ao vocábulo "hermenêutica”, faz-se necessário um breve recorte histórico das concepções que o respectivo termo foi assumindo. E, como tal, os estudos de Jean Grondin (2012) servem ao nosso intento. Consoante o estudioso, a "hermenêutica" pode ser compreendida em três acepções, a saber: (1) o sentido clássico; (2) o momento representativo de uma pretensa filosofia universal e (3) a hermenêutica da era "pós-moderna".

No primeiro momento - mais precisamente até o século XVII -, ela se revela como disciplina auxiliar na "arte de interpretar os textos". Investida de toda uma pretensão normativa (com regras e preceitos baseados na retórica), funcionava como aparato de uma prática de interpretação que garantisse fidedignidade e o "bem interpretar" dos textos.

No segundo momento, a partir de uma nova concepção inaugurada por Dilthey no século XIX, ela é adotada como aparato metodológico às ciências humanas. "A hermenêutica se torna, assim, uma reflexão metodológica sobre a pretensão de verdade e o estatuto científico das ciências humanas" (GRONDIN, 2012, p. 13). e à qual se atribui o mérito de garantir uma "condição de respeito" às ciências humanas e sociais.

Por sua vez, a terceira concepção de hermenêutica assume, no século XX, o status de "filosofia universal da interpretação" e encontra em Heidegger um alargamento do sentido e da interpretação, já que o filósofo situa a atividade interpretativa num processo que ultrapassa a uma mera “arte da interpretação” ou mesmo a um simples suporte metodológico. A concepção heideggeriana amplia a interpretação para os domínios da própria existência que, segundo o filósofo, já é perpassada por interpretações. Desse modo, em reação à "hermenêutica de textos" nasce uma "hermenêutica da existência".

A partir de tais conceitos e, reportando ao título, pode-se considerar o referido prefácio como uma proposta de obra (e de leitura) que incide sobre uma "hermenêutica" caracterizada também pela possibilidade de "fios de leitura" (aletria) que: primeiramente, são 
"enrolados" num processo de construção e constituição da obra; e, secundariamente, esta é disponibilizada ao leitor (ou crítico) para um futuro "desenrolar" no processo de (re)construção e (re)criação de "fios de sentidos". Nesse processo, "fios" de significados se "emaranham", se amalgamam, se "enrolam" dentro das possibilidades de leitura que a obra permite e que, voluntariamente, conduz o leitor a tal caminho (de hermenêuticas).

Está aí uma peculiaridade de Tutameia: a de propor uma hermenêutica que, num procedimento paradoxal, tanto investe na busca de (um) significado(s) subjacente(s) a um "fundo de palavra", como viabiliza possibilidades de leitura (interpretações) que vão além do que está "inscrito” na palavra ou do que se encontra em vias de direcionamento no todo da obra. São os "fios” que, "enredados" delimitam sentidos na mesma medida em que, quando "desenrolados", deles "brotam" hermenêuticas diversas que abrem possibilidades para a construção de significados tanto da obra quanto da vida.

Tem-se em "Aletria e hermenêutica" o filosófico mediatizado pelas blagues; as sutilezas da vida e da obra tratadas seriamente por recursos cômicos. Aí o corriqueiro e simples da vida, mediante a aparente e simples "brincadeira", sugere uma "hermenêutica" atinente ao profundo do "fundo" da existência, assim como acerca do fazer literário. Ademais, tais trivialidades apresentam-se como sugestões temáticas para o trabalho tanto do poeta e prosador quanto do filósofo.

Proposta essa que pode ser associada aos contrassensos que, conforme Wittgenstein (apud HADOT, 2014), funcionam apenas no nível da reflexão filosófica e da linguagem poética. Esse “desnível” entre o profundo da vida e o caótico do representar da linguagem é compensado, na obra rosiana, pelos mesmos recursos estilísticos, assim como por outro recurso um tanto inusitado que em "Aletria e hermenêutica" se revela como pioneiro na ficção do autor: fazer da anedota, ou da linguagem figurada, um instrumento filosófico e poético que - se não revela claramente o simples e, paradoxalmente, o complexo e inexprimível da vida -, pelo menos, sugere o "não dizível” pelo “apresentável” dos "contrassensos". É o que o autor mineiro deixa evidente na seguinte nota: 
Enquanto, com desconto, minimiza nota opressiva o exemplo de não-senso dado por Vinicius de Moraes, que o traduziu do inglês:

"Sobre uma escada um dia eu vi

Um homem que não estava ali;

Hoje não estava à mesma hora.

Tomara que ele vá embora." (ROSA, 2009, p. 38)

\section{"Hipotrélico": criação e inovação linguística}

Outro aspecto marcante da obra de Guimarães Rosa se revela pelo trabalho de reflexão que o autor confere à linguagem. Esse processo de refletir sobre a língua em ação concomitante com a produção de uma nova linguagem - neologismos - constitui o tema do segundo prefácio de Tutameia. Publicado primeiramente, em 1961, no jornal O Globo, eis, depois em Tutameia, "Hipotrélico", o prefácio que, também ao estilo anedótico, se revela numa maneira tão bem humorada quanto criativa de abordar o processo de criação linguística:

Há o hipotrélico. O termo é novo, de impesquisada origem e ainda sem definição que lhe apanhe em todas as pétalas o significado. Sabe-se, só, que vem do bom português. Para a prática, tome-se hipotrélico (grifo do autor) querendo dizer: antipodático, sengraçante imprizido; ou, talvez, vice-dito: indivíduo pedante, importuno agudo, falto de respeito para com a opinião alheia. (ROSA, 2009, p. 106)

Como se observa no excerto, logo de início já se patenteia o caráter metalinguístico do prefácio. De maneira inusitada e jocosa, Rosa faz uso de um neologismo para justificar a pertinência da adoção ou aceitação dos neologismos como um processo natural e enriquecedor da língua. Tal procedimento se assenta num jogo metalinguístico - efetivado em fábula - através do qual a adoção do neologismo "hipotrélico" - que, aliás, também é o título do prefácio - funciona como recurso de questionamento acerca do comodismo das pessoas ante a língua convencionalmente aceita, aquela ajustada aos "bons hábitos estadados" (ROSA, 2009, p. 106). "Hipotrélico" constitui, em Tutameia, o ponto ou a paragem central de reflexão sobre o uso efetivo da língua e suas consequências no processo de desenvolvimento natural do idioma. 
E a ironia da anedota, também referida como "fábula", incide na contraditória - e paradoxal - circunstância de que o "hipotrélico" é justamente aquele que é avesso ou intolerante àquilo que se revela como ilustração viva do processo de "hipotrelismo" (neologismo). Na circunstância da estória, o "hipotrélico" nega a si mesmo enquanto existência (em neologismo), enquanto direito de ser usado (ou de uso). Trocando em miúdos: o "neologista" nega o próprio neologismo embora seja um produtor e usuário em potencial do "hipotrelismo".

Entrevê-se aí uma crítica do autor endereçada àqueles que se dizem defensores do idioma "puro", àqueles que não veem com "bons olhos" o fato de "autônomos", ou melhor, pessoas "não autorizadas" serem responsáveis por alterações ou mudanças na língua dita oficial.

Mais precisamente em Tutameia, o trabalho performativo do autor se faz sensível às "Palavras em serviço efetivo, já hoje viradas naturais, com o fácil e jeito e unto de espontâneas, conforme o longo uso as sovou” (ROSA, 2009, p. 107). Eis aí um projeto que se justifica pela máxima: "E, donde: palavra nova, só se satisfizer uma precisão, constatada, incontestada" (ROSA, 2009, p. 107).

Daí se vislumbrar, no aludido prefácio, a proposta de Rosa quanto à criação de uma nova língua: que consiga "tapar o vazio", que sejam "palavras em serviço efetivo" e que, antes de tudo, o responsável por tal empreendimento seja "agreste ou inculto o neologista, e ainda se analfabeto for". (ROSA, 2009, p. 107). Hipotrélico constitui, em suma, um neologismo e é, ao mesmo tempo, o termo que designa aquele que se mostra avesso ou resistente aos neologismos. Ademais, os "rústicos da roça" se destacam como aqueles que:

Palavrizam autônomos, seja por rigor de mostrar a vivo a vida, inobstante o escasso pecúlio lexical de que dispõem, seja por gosto ou capricho de transmitirem com obscuridade coerente suas próprias e obscuras intuições. São seres sem congruência, pedestres ainda na lógica e nus de normas. (ROSA, 2009, p. 108).

Assim, o sertão é lugar propício para tal proeza; é onde a língua se delineia e cresce; mostra-se viva independentemente da lógica, despida de normas ou convenções. O sertão 
aí se consagra como o local de muitos "hipotrélicos" - tanto de criadores (sertanejos falantes), como de criaturas (neologismos). O que Rosa deixa evidente no trecho:

“[...] No sertão há dessas expressões; nascem ninguém sabe como; vivem eternamente ou desaparecem um dia sem também se saber como.” Confere. Pode-se lá, porém, permitir que a palavra nasça do amor da gente, assim, de broto e jorro: aí a fonte, o miriquilho, o olho d'água; ou como uma borboleta sai do bolso da passagem? (ROSA, 2009, p. 108)

Por outro lado, conquanto o autor seja adepto da ideia de que tal processo de desenvolvimento da língua se dê de maneira natural, ele não descarta aquelas palavras cuja origem se deu por uma intenção e cuja frequência de uso fê-las tornarem-se naturais, são aquelas

[...] - ao modo como Cícero fez qualidade ("qualitas"), Comte altruismo, Stendhal egotismo, Guyau amoral, Bentham internacional, Turguêniev niilista, Fracástor siffilis, Paracelso gnomo, Voltaire embaixatriz. ("ambassadrice"), Van Helmont gás, Coelho Neto paredro, Rui Barbosa egolatria, Alfredo Taunay necrotério; e mais e mais e mais, sem desdobrar memória. Palavras em serviço efetivo, já hoje viradas naturais, com o fácil e jeito e unto de espontâneas, conforme o longo uso as sovou. (ROSA, 2009, p. 107)

Nesse sentido, "Hipotrélico" apenas ratifica uma postura de Rosa cuja prática já se mostra recorrente na sua produção e cujo compromisso se revela, ademais, na iniciativa de delegar à dita obra literária um espaço representativo de uma modalidade linguística que se efetiva fora dos chamados grupos "intelectualizados" ou "acadêmicos" e cuja prática linguística condiz com aquela politicamente considerada de prestígio.

\section{"Nós, os temulentos": a dubiedade da ficção e das coisas da vida}

De fato, a organização de Tutameia é garantida, sobretudo, pelos prefácios, o que se dá de uma maneira tão séria quanto agradável e descontraída. O conto "Nós, os temulentos", por exemplo, funciona tanto como anedota quanto instrumento e espaço de digressões que ultrapassam os limites do espaço narrativo. Tem-se aí o humor que disfarça o sério; a aparente brincadeira que instrui (e "teoriza") ao mesmo tempo em que provoca o 
riso. Aí o performativo se revela de maneira tal, que chega fazer do engraçado da "temulência" algo que consegue, da mesma maneira, fazer do leitor "ébrio de riso".

O início do prefácio já vislumbra uma preocupação do autor com os dramas próprios da vida, procedimento esse que destoa do clima de humor que perpassa quase toda a estória. Observa-se como o clima anedótico serve apenas para disfarçar o profundo e sério da questão crucial que perpassa a narrativa: as inquietações do homem se veem camufladas pelo aparente ridículo do comportamento do protagonista Chico.

Pode-se dizer que em "Nós, os temulentos", a reflexão se apresenta muito mais revestida de anedota do que de prefácio propriamente dito. Trata-se de um motivo "teórico" e filosófico camuflado em estória (conto). Aliás, uma maneira interessante de prender o leitor numa aparência tão "despojada" tão quanto mais convidativa para direcioná-lo a um assunto mais sério que perpassa a narrativa: eis as proezas estruturais da obra em função da reflexão acerca das inquietações do homem no mundo.

Considerando a perspectiva do prefácio em questão, Tutameia encerra em si, assim como os outros prefácios, o projeto rosiano de efetivar a obra na mesma medida em que vislumbra as dicas e orientações acerca da respectiva obra e da sua relação com as inquietações do homem e com as circunstâncias da vida. A visão duplicada do bêbedo, por exemplo, metaforiza - simultaneamente - a dupla possibilidade de leitura da obra literária, bem como a visão dupla acerca do mundo.

Num processo anedótico, a embriaguez do personagem Chico é pretexto de questionamento atinente à dúbia possibilidade de efetivação da linguagem, assim como uma forma de aludir à dupla interpretação que um texto literário suscita - nesse caso específico, a própria obra Tutameia -. Remete, ademais, a uma ambiguidade de sentidos acerca da realidade (do mundo, da vida), o que, no conto, é alegorizado por uma circunstância tanto humorística quanto ridícula, que é a do temulento.

Para o temulento, Chico, dúbia não só é a visão, mas também a possibilidade de transitar por vias de mão dupla: "E atravessou a rua, zupicando, foi indagar de alguém: Faz favor, onde é que é o outro lado? - Lá... - apontou o sujeito - Ora! Lá eu perguntei, e me disseram 
que era cá...” (ROSA, 2009, p. 153); é conhecer o estado de sobriedade tão quanto o da embriaguez: “- E você, seu bêbado!? - megerizou a cuja. E, aí, o Chico: - Ah, mas... Eu? ... Eu, amanhã, estou bom..." (ROSA, 2009, p. 152); é circular por entre a "realidade" e o devaneio, entre o empírico e a ficção. Aí duas realidades que se fundem e se confundem, mas que também se chocam: "terra firme" versus "mundo-da-lua":

E retornou, mistilíneo, porém, porém. Tá que caiu debruçado em beira de um tanque, em público jardim, quase com o nariz na água - ali a lua, grande, refletida - Virgem, em que altura eu estou!... (ROSA, 2009, p. 153)

Ademais, dois são os lados (opostos) em cuja experiência tem-se a incerteza, o titubear diante da inadiável circunstância de escolha. A contínua insistência da vida em impor opções de "realidade", e a constante dúvida do temulento entre o instável e nada seguro (meio-fio) e o estável e cômodo chão "firme":

[...] E torna que, se-soerguido, mais se ia e mais capengava, adernado: pois a caminhar com um pé no meio-fio e o outro embaixo, na sarjeta. Alguém, o bom transeunte, lhe estendeu mão, acertandolhe a posição. - Graças a Deus! - Deu. - Não é que eu pensei que estava coxo? (ROSA, 2009, p. 153)

A insistência no "prosseguir" da vida que, paradoxalmente, tanto chama o nosso Chico para uma realidade "exata" tão quanto o convida para uma "viagem" menos fatídica, mais "ébria". Eis o hesitar entre dois mundos ou duas "realidades" diversas; o titubear entre o ir e o vir: "E foi de ziguezague, veio de zaguezigue." (ROSA, p. 154).

Diante do duplo da "realidade" - entre a lucidez e a temulência, entre o ser e o não ser -, eis que também se faz o duplo da visão: “ - Estou, não estou... - Então, ande reto nesta linha do chão./ - Em qual das duas? (ROSA, 2009, p. 154, grifos do autor).

Aí tanto o conceito de linguagem - pretensamente referencial - quanto a concepção de "realidade" entram em xeque. A instabilidade mental gerada em consequência do estado de embriaguez do personagem corresponde à mesma instabilidade em que é posta a concepção de realidade e de verdade: “- 'Quando... - levantava doutor o indicador - ... quando eu achar que esses dois dedos aqui são quatro'... [...]” (ROSA, 2009, p. 151). 
Chico é aquele que tem como experiência duas opções de vida, ou seja, duas opções realidade e, por conseguinte, duas visões (ou concepções) de mundo. Para ele, o único momento em que "fugir da vida" é sinônimo de "fugir da realidade" é aquele em que o sonho - literalmente originário do ato de dormir - ganha espaço: "E, com isso, lançou; tumbou-se pronto na cama; e desapareceu de si mesmo" (ROSA, 2009, p. 155, grifo nosso).

O estado de temulência é uma realidade que insiste em se misturar com as circunstâncias da realidade imediata. Há uma permanente confusão entre o senso e o não senso, entre "realidade" e delírio (fantasia):

E, hora depois, peru-de-fim-de-ano, pairava ali, chave no ar, na mão, constando-se de tranquilo terremoto. - Eu? Estou esperando a vez da minha casa passar, para poder abrir... Meteram-no a dentro (ROSA, 2009, p. 154).

Tal façanha do autor obriga o leitor a considerar duas ou mais possibilidades de "realidade" ou de "hermenêutica" e cuja ilustração pode ser, mais ou menos, assim vislumbrada: a condição da dupla visão própria do embriagado (da anedota) pode ser associada à mesma condição em que se encontra o leitor quando da prática da leitura, que é a possibilidade de enxergar ou de "construir" duplamente "realidades" ou leituras dentro das condições que a obra permite. Além disso, pode-se associar à dupla (ou mais) possibilidades de interpretação ou de pontos de vista acerca da obra.

O autor aí deixa entrever um compromisso com as contradições e desequilíbrios da vida e, consequentemente, com a restauração daquilo que poderia manter em equilíbrio o contínuo "prosseguir" da vida sertaneja.

E é especialmente com "Nós, os temulentos” que o autor encontra uma maneira um tanto divertida, uma circunstância aparentemente de riso para fazer repensar os conceitos de vida, de arte, de linguagem, de "realidade", de leitura e de obra. Rosa consegue, assim, desestabilizar conceitos "fechados" não só de língua ou de interpretação, o autor consegue, ademais, relativizar valores consagrados acerca da "realidade" da obra literária e de "verdades" da vida. Rosa, desse modo, lança mão de uma "hermenêutica" que não só relativiza a concepção de verdade, mas também a concepção de leitura e do fazer literário. 


\section{"Sobre a escova e a dúvida": a ficção se confunde com a vida}

Publicado inicialmente como crônica em 15 de maio de 1965 no semanário Pulso, "Sobre a escova e a dúvida" constitui o mais extenso e talvez o mais complexo dos prefácios, não somente pela maior variedade de motivos, mas, sobretudo, pelo jogo simultâneo de ilusão e dúvida que o autor imprime à narrativa. De leitura densa, o prefácio é constituído de sete partes, todas elas introduzidas por epígrafes, que variam em número de um a três, e, ainda, complementado por um glossário ao final do texto.

Em "Sobre a escova e a dúvida", narrador, personagem e autor se misturam e se confundem a ponto de se tornar inviável delimitar as três vozes que constituem a narrativa: se se trata do narrador em primeira pessoa, ou do personagem trazido por esse narrador, ou mesmo do próprio Guimarães Rosa - ao que parece, é representado tanto pelo narrador quanto pelo personagem de quem aquele - narrador - fala e com quem conversa -. Vida e ficção se misturam a tal ponto que se torna impossível distinguir personagem e autor, assim como impossível delimitar as confissões disfarçadas em ficção ou a ficção camuflada em revelação.

Inicialmente, narrador e personagem conversam sobre experiências do fazer literário, de modo que ambos se identificam e se revelam mutuamente personagem um do outro. Ao mesmo tempo, as confidências trocadas permitem inferir que, em ambas as circunstâncias, parece se tratar do próprio Guimarães Rosa numa revelação dos mecanismos inerentes ao seu processo de criação da escrita. Quanto a esse aspecto, a maior parte da crítica da obra do autor reconhece no personagem Roasao, do referido prefácio, uma persona do próprio Rosa. Vera Novis, por exemplo, afirma ser um alter ego do escritor: “[...] a conclusão é que Tutameia é a estória de Guimarães Rosa - sua própria trajetória” (NOVIS, 1989, p. 118).

Nesse momento primeiro, narrador e personagem compartilham emoções, confidências, fazem reflexões sobre a vida: felicidade, dor, dúvidas, solidão, obrigações, convenções e, sobretudo, a necessidade de se escrever sobre tais aspectos da vida. Daí a incerteza 
de que "Um escrito, será que basta? Meu duvidar é uma petição de mais certeza" (ROSA, 2009, p. 213), uma vez que “-Tem-se de redigir um abreviado de tudo" (ROSA, 213).

Nessa mistura entre vida e ficção, há o momento em que o narrador faz alusão a um livro cuja autoria é atribuída a Gilberto Freyre e que tem como título Dona sinbá e o filho padre, e cujo personagem coincide com uma certa senhora que, até o momento da criação da obra, não era conhecida do respectivo autor. Há, no citado episódio, uma confusão e uma coincidência de identidade entre o personagem fictício da citada obra e a pessoa sobre quem o narrador do mesmo romance assegura fazer parte da dita "vida real":

Pois o que vinha acontecendo comigo era uma aventura inesperada e única. Onde e com quem já acontecera coisa igual ou semelhante? Nos meus livros ingleses sobre fatos chamados pelos pesquisadores modernos de fenômenos psíquicos, de supranormais, eu não deparara com a relação de um fenômeno que se parecesse com aquele: com aquela Dona Sinhá real a me dar provas de que era a mesma figura de minha concepção romanesca. (ROSA, 2009, p. 224)

Tal enleio e dúvida, quanto ao se tratar da ficção ou da "realidade", se processam gradativamente até chegar ao ponto em que não restam dúvidas de que quem fala é o próprio Rosa.

Observa-se, no prefácio em questão, como Rosa engendra um jogo ilustrativo - tão quanto nebuloso - de como a vida, dita real, se processa pela arte na mesma proporção em que a obra se perfaz, ou se revela, em vida, dita realidade. Diante da insuspeitada dificuldade de se discernir entre o "inventado fazendo realidade" (ROSA, p. 223) e a realidade pretensamente contrária ao inventado, o autor faz da obra uma problematização da vida pretensamente real tão quanto da vida figurada na obra. Vida e obra se fundem e se confundem na mesma dimensão em que se nos apresenta o certo/incerto, o verdadeiro/falso da vida. Com esse mecanismo, Rosa realiza um processo também duplo: desestabiliza tanto o conceito de obra ou de arte quanto o conceito de realidade; põe em xeque "a escova" e deixa como sugestão a contínua "dúvida".

De cunho eminentemente filosófico, nesse jogo "vida/ficção", o prosador imprime tal dúvida que perpassa - tão quanto mais se complica - todo o texto. Afinal, o que de 
início parece se revelar como ficção, adiante se confunde com a "realidade". Procedimento esse que também imprime a dúvida no leitor, ou crítico, de como classificar o texto (dito prefácio): se em narrativa (ficção), se uma espécie de diário (confissões), ou mesmo se em um inovador e aparente simples pretexto para reflexões sobre a vida, bem como "teorizações" sobre o processo de construção literária.

O narrador já abre o prefácio com três epígrafes cujas reflexões incidem sobre inquietações e dúvida do homem acerca da vida. As reflexões sugeridas partem da premissa de que nada é certo, de que tudo é incerto e de que a vida é cheia de "misteriousanças". A "verdade" é, portanto, algo da qual não se tem certeza nenhuma: "Meu duvidar é da realidade sensível aparente - talvez só um escamoteio das percepções” (ROSA, 2009, p. 212). Nesse sentido, não é por acaso a alusão ao filósofo Sextus Empiricus cujo pensamento questiona a pretensão da verdade absoluta.

O momento mais significativo do prefácio se revela num episódio aparentemente irrelevante trazido na parte V. O narrador rememora o tempo de quando era menino (que parece também se tratar do ficcionista quando criança), em que se via obrigado a escovar os dentes: "Menino, mandavam-me escovar em jejum os dentes, mal saído da cama. Eu fazia e obedecia." (ROSA, p. 221). Por ainda não se dar conta da ausência de necessidade de proceder a tal exigência - visto que ainda estava em jejum desde o momento em que fez a escovação antes de dormir -, o comportamento do menino não contrariava o esperado. Não obstante, mais tarde, eis que "Até que a luz nasceu do absurdo" (ROSA, p. 221), eis a descoberta da "escassa autonomia de raciocínio" (p. 221) e, depois disso, a consequente indagação acerca da falta de pertinência quanto ao cumprimento do "[...] velho, consagrado, comum modo, o que cedo impunham. Cumpram o inexplicável” (ROSA, 2009, p. 221) e, portanto, a consequente mudança de comportamento.

Tal episódio é, aqui, enfatizado por, de fato, justificar o título do prefácio. Na verdade, ele metaforiza as circunstâncias em que nossas atitudes e ações se mostram em conformidade com as regras, princípios, valores e papeis previamente delimitados pelo meio social no qual estamos imersos. O título já remonta à circunstância de a "verdade" ser 
resultado de uma criação, um acordo, ou convenção. A “escova”, por exemplo, constitui a metáfora das imposições, do comportamento do indivíduo que se justifica pela aceitação passiva, ou não questionada, das atribuições e limites impostos pela família, pelas instituições, enfim pela sociedade. Tal metáfora da escova se encaixa, portanto, nas circunstâncias em que somos obrigados a aceitar o convencional, ainda que este não corresponda às nossas necessidades e interesses reais. De tal modo:

Respondam-me - mulheres, homens, crianças, médicos, dentistas que usam o velho, consagrado, comum modo, o que cedo me impunham. Cumpram o inexplicável. (ROSA, 2009, p. 221)

Por outro lado, diante da constatação de que nem sempre é pertinente agir conforme o esperado, a opção pode ser aquela que - se não numa atitude de subversão - seja a de questionar a validade das imposições; ou seja aquela que abra espaço para a dúvida. Eis aí a opção do menino: a dúvida diante do imposto, a contrariedade em vez da "escova".

Considerando o processo de criação literária, pode-se pensar no prefácio como um desafio que Rosa propõe tanto para o leitor (enquanto crítico) quanto para outro autor: pensar a viabilidade de optar entre a forma convencional de leitura e de escrita - a escova - e a possibilidade de subverter essa mesma ordem ou convenção - a dúvida. A segunda opção já pressupõe novas concepções, novas perspectivas de escrita e leitura, novos caminhos a trilhar durante o processo de criação e de recepção da obra literária. Eis aí - talvez - a proposta embutida em Tutameia.

E, nesse sentido, o autor também se mostra cônscio da repercussão ou consequência da sua ação em subverter o convencional; ele já presume uma avaliação ou mesmo resistência por parte daquele(s) que está(ão), involuntariamente, preso(s) às convenções previamente instituídas por um dado grupo (social, acadêmico, por exemplo). Eis a defensiva inscrita na epígrafe que propõe uma "suspensão de julgamento":

A fim, porém, de poder-se ter mais exata compreensão de tais antíteses, darei os Modos de conseguir-se a suspensão de 
julgamento.

Sextus Empiricus. (ROSA, 2009, p. 220)

É, para o escritor, um desafio como que a lançar um olhar sobre o que não se mostra como preocupação para os outros, uma espécie de "Se todos tivéssemos nascido já com uma permanente dor - como poder saber que continuamente a temos?” (ROSA, p. 215): eis, talvez, a dificuldade - seja do indivíduo, seja do escritor - de se eximir das convenções e papeis que, contínua e involuntariamente, se apresentam como naturais para aqueles que a efetivam. Eis, talvez, o papel do último prefácio: fazer coincidir todas as propostas presentes nos prefácios anteriores e, portanto, de culminar a essência temática (e teórica) das Terceiras estórias.

Afinal, "Tudo tinha de destruir-se, para dar espaço ao mundo novo aclássico, por perfeito” (ROSA, p. 210). Daí o sonho (ou um projeto) de livro:

[...] Pelo que pensava, um livro, a ser certo, devia de confeiçoar da parte de Deus, depor paz para todos, virtude de enganar com um clareado a fantasia da gente, empuxar a coragens. Cabia de ir descansando o feio mundo morrinhento; não se há de juntos iguais festejar Judas e João Gomes. (ROSA, 2009, p. 230)

Donde a necessidade, a "incumbência" de "se redigir um abreviado de tudo": neste também haverá de caber um espaço - mesmo que pensado - para a "felicidade":

-É o que mais se parece com a "felicidade": um modo sem sequência, desprendido dos acontecimentos - camada do nosso ser, por ora oculta - fora dos duros limites dos desejos e das razões horológicas. (ROSA, 2009, p. 214)

A razão do livro se justifica, assim, pela ausência (ou excesso) de razão das coisas, da vida. E, se a "vida também é para ser lida", o livro pode responder - ainda que timidamente - pelas supostas razões (ou "desrazões"?) que a vida, na sua simples e ao mesmo tempo complexa existência, teima em velar quando ao se revelar.

Por assim dizer, prefácio faz de Tutameia uma obra cujo fundamento dispensa qualquer juízo de valor: conquanto subversiva, já se coloca - tão quanto coloca a vida - na defensiva quanto à "suspensão de julgamento": 


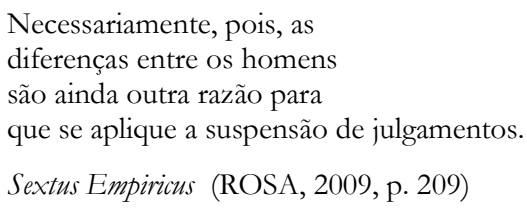

Desse modo, a suspensão de julgamento se faz necessária visto que, aqui, a verdade é uma possibilidade que pode estar seja na vida, seja na obra. A tentativa de verdade da obra pode não implicar aquilo que se quer como verdade da vida, e vice-versa. Contudo, ambas podem ser ou não verdades. E, nesse sentido, Tutameia se configura como obra que não dita "a verdade" (da obra ou da vida), mas que aponta ou projeta possibilidades de obra e de mundo cujas verdades extrapolam - e muito - nossa condição ou autorização de arriscar um "juízo de valor". Nesse caso, em se tratando da proposta de Tutameia, entre a "escova", verdade absoluta, e a dúvida acerca da suposta verdade, a segunda opção parece ser a mais plausível porquanto dá vazão a possibilidades de "verdades", seja no processo de construção da obra, seja no contínuo "construir" da vida.

Se, com esse mecanismo, Rosa não manifesta compromisso com uma "verdade", tampouco o leitor, ou crítico, pode validar uma leitura ou hermenêutica como a "verdade" ou sentido absoluto da obra, já que, conforme discussão aqui, esta se configura como sucessivos e infindáveis "fios de hermenêuticas" que, "desenrolados", abrem caminhos para infinitas verdades que, paradoxalmente, se sustém de dúvidas. Dessa forma, o prefácio funciona como um instrumento de reflexão sobre a vida e sobre a obra, de tal modo que tanto a vida se revela camuflada em obra quanto a obra camuflada em vida.

Se, entre "a escova" e "a dúvida", a vida, (fora da obra) reserva ao sujeito o livre arbítrio, a obra talvez possa operar com uma ação que a própria vida às vezes teima em velar: a adoção da dúvida. Em Tutameia, ficção e realidade se misturam, mas somente na medida em que uma possa contribuir com a outra na continuidade de uma - ininterrupta - perseguição à dúvida. Nesse intento, Rosa faz suas as palavras de Sêneca:

“[...] De todos te ofereço, cabendo-te à vontade decidir se a indagação deve prosseguir - 


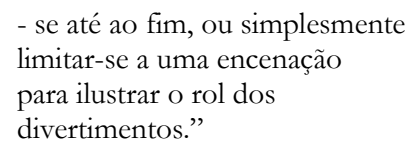

Sêneca (ROSA, 2009, p. 221)

Nesse caso, "No plano da arte e criação" (ROSA, p. 222) a vida fica em equivalência com a obra: é suscetível de dúvida tão quanto se faz impossível a tarefa de se atingir a verdade absoluta. Do mesmo modo, tanto a obra quanto a vida merecem, e devem, ser lidas. Afinal, se em "Aletria e hermenêutica", Rosa deixa tácita a ideia de que "A vida também é para ser lida.” (2009, p. 30), a obra pode ser o instrumento que, não só permite, como também revela - e desvela - essa vida.

Em se tratando de projeto de vida, a opção pela condição de dúvida - em detrimento da condição de "escova" - se revela numa adoção de vida que extrapola, e muito, a simples aceitação de uma vida "exata", "fechada", e vai em direção a um contínuo "construir" modos de vida cujas "verdades" ou "mentiras" nunca se exaurem. Eis a viabilidade de se viver num ininterrupto fluir de dúvidas. Afinal, se arriscada e fracassada foi a atitude de Plínio, o Velho, quando ao tentar se certificar do "exato" da erupção do Vesúvio [Cf. epígrafe $1^{a}$ Tabuleta, ROSA, 2009, p. 209), tão quanto frustrada pode ser a tentativa de manter no "estagnado" ou no "verdadeiro" aquilo que, naturalmente, se altera, caminha, flui, muda... E a perspectiva rosiana com Tutameia é a de que, se não existe uma verdade de vida, tampouco a pretensão de uma verdade de obra.

\section{O processo metalinguístico em Tutameia}

Há, em Tutameia, um desdobrar simultâneo de obra: em prática e teoria, em prosa/poesia e filosofia, reflexões e digressões, histórias e estórias e, sobretudo, a metalinguagem embutida na linguagem é o que garante a Tutameia um diferencial em relação à produção anterior do autor.

E esse caráter metalinguístico imanente à Tutameia se patenteia, ademais, no conto "Desenredo" cujo título já alude a um modo de narrar "às avessas” em relação à forma 
convencional da escrita em prosa. A narrativa traz como protagonista Jó Joaquim, cuja experiência de vida amorosa serve, conforme o narrador, de motivo a ser transformado em fábula. Vítima de infidelidade por parte da esposa - Livíria, Rivília ou Irlívia - Jó Joaquim adota seus próprios mecanismos de reconstrução da vida sentimental. Nesse sentido, a decisão do protagonista recai numa opção que, não obstante contrariar opiniões e concepções alheias, figura como aquela que permite a Jó Joaquim a satisfação de uma vida amorosa realizada.

Considerando a forma como o narrador enfatiza a opção de vida do protagonista, a concepção de "enredo" entra em xeque, já que a forma de narrativa convencionalmente aceita é aquela que tende a um fim (de estória) já esperado, ou previamente definido conforme expectativa do leitor ou de um grupo acadêmico específico.

O fim da história de Jó Joaquim (na estória) - que, por sinal, contraria a expectativa das pessoas com quem ele convivia ou mantinha laços de amizade e esperavam dele uma atitude de firmeza - serve como pretexto para se repensar o final costumeiramente adotado nas narrativas tradicionais. O personagem age na perspectiva que contraria as pessoas, assim como a narrativa "posta em ata” difere daquela já esperada. Assim, Jó Joaquim “desenreda" o enredo para "enredar" a própria estória e chegar ao almejado da experiência (história) de vida: "E pôs-se a fábula em ata” (ROSA, 2009, p. 75). É “a história que se quer estória". São os enredos da vida ou da história nos enredos/desenredos da estória. É a ficção que quer fundir-se na vida com a mesma intensidade com que a vida se funde e se confunde com a ficção.

A obra configura-se como um trabalho estilístico que permite refletir tão quanto projetar um mundo de possibilidades. É, assim, a história que se revela pela estória; é “A estória (que) não quer ser história", conforme proposta do prefácio "Aletria e hermenêutica".

A bem dizer, procedimento análogo se observa em Tutameia: um trabalho engenhoso com o signo cujo efeito contempla não só a obra enquanto literatura, mas também 
enquanto conteúdo. Tutameia consegue ser e dizer, falar e se revelar: dizer o mundo, a vida ao mesmo tempo em que se revela como obra em vida literária, assim como vida em obra.

Daí dizer que o trabalho de Rosa com a linguagem consegue relativizar conceitos na medida em que (des)normatiza convenções e (re)cria possibilidades de sistematização e adoção de novas palavras e regras, de novas estruturas e linguagens. Dessa maneira, o autor mineiro, com Tutameia, consegue fazer da obra algo que é, ao mesmo tempo, a "teoria” e a prática, a obra e a vida, uma vez que ele não só relativiza parâmetros, como também nos apresenta uma proposta - teórica e prática, filosófica e poética - um tanto inovadora do fazer literário e da sua relação com a vida. Rosa, dessa maneira, incita-nos a repensar (e considerar) diferentes formas de vida, de mundo, de língua e - por que não? - também de obra.

\section{TUTAMEIA: THE LANGUAGE AND STRUCTURE OF WORK IN TUNE WITH THE (I) LOGIC OF LIFE}

O presente artigo traz em seu bojo o papel inusitado que Guimarães Rosa confere aos prefácios quando da construção e estruturação da obra Tutameia. Discute-se como a(s) temática(s) e estruturação da referida obra já se revelam pela organicidade dos prefácios: os motivos já se delineiam em quatro narrativas que funcionam, a um só tempo, como prefácios e como histórias que complementam o repertório dos quarenta contos que compõem a obra. Vislumbra-se, desse modo, como tais prefácios conseguem amalgamar reflexões, pistas de leitura e escrita, metalinguagem, histórias e estórias, conservando, simultaneamente, a integridade (dos prefácios e demais narrativas) e a garantida dos elementos constitutivos do todo de obra que é Tutameia. Jogo performativo esse com que o prosador nos dá uma amostra de obra que não só questiona o próprio fazer literário, como também reflete e nos apresenta amostra(s) de vida, que - assim como a obra - apresenta seus inesgotáveis motivos que merecem (e devem) ser lidos.

ABSTRACT: This paper points out the unusual role that Guimarães Rosa gives to prefaces to construct and structure the short stories book Tutameia. The theme(s) and structuring of this work are already revealed by the organicity of the prefaces: the themes are already delineated in four narratives that work, at the same time, as prefaces and as stories that complement the repertoire of the forty narratives that make up the work. Thus, we can see how such prefaces can amalgamate reflections, reading and writing clues, metalanguage, histories and stories, while preserving the integrity (of the prefaces and other narratives) and the guarantee of the constitutive elements of the whole work that it's Tutameia. This performative game with which the prospector gives us a kind of work that not only questions the literary practice itself, but also reflects, questions and presents us a sample of life, which - like the work - presents its inexhaustible reasons that deserve (and should) be read.

KEYWORDS: Guimarães Rosa; Prefaces; Metalinguistic procedure; Structure; Tutameia. 


\section{REFERÊNCIAS}

FANTINI, Marli. Guimarães Rosa: fronteiras, margens, passagens (Org.). Belo Horizonte: Editora UFMG, 2008.

GRONDIN, Jean. Hermenêutica. Trad. Marcos Marcionílio. São Paulo: Parábola Editorial, 2012.

HADOT, Pierre. Wittgenstein e os limites da linguagem. Trad. Flavio Fontenelle e Loraine Oliveira. 1. ed. São Paulo: É Realizações, 2014.

LORENZ, Günter. Diálogo com Guimarães Rosa. In: ROSA, João Guimarães. Ficção completa. Rio de Janeiro: Nova Aguilar, 1995.

NOVIS, Vera. Tutameia: engenho e arte. São Paulo: Editora Perspectiva, 1989.

NUNES, Benedito. A Rosa o que é de Rosa: literatura e filosofia em Guimarães Rosa. Org. Victor Sales Pinheiro. Rio de Janeiro: DIFEL, 2013. . O dorso do tigre. São Paulo: Editora Perspectiva, 1969.

REVISTA BULA. Conversa com escritores brasileiros. 24 de novembro de 1966.

ROSA, João Guimarães. Tutameia: terceiras estórias. 9. ed. Rio de Janeiro: Ediouro Publicações, 2009.

SIMÕES, Irene Gilberto. Guimarães Rosa: as paragens mágicas. São Paulo: Perspectiva: Editora da Universidade de São Paulo, 1988.

Recebido em: 25/05/2019.

Aprovado em: 14/07/2019. 